\title{
The Use of 3x3 Matrix to Evaluate a Manufacturing Technology of Aluminium Systems for Building Industry
}

Manuela Ingaldi, Stanisław Borkowski, Dorota Klimecka-Tatar, Piotr Sygut

Czestochowa University of Technology, Faculty of Management, Institute of Production Engineering

al. Armii Krajowej 19b, 42-200 Czestochowa, Poland, E-mail: manuela@gazeta.pl, bork@zim.pcz.pl, klimt@wip.pcz.pl, piotr.sygut.wz@gmail.com

Different types of aluminium systems are popular in building industry. Manufacturing technology of such products is a very important factor influencing the final result of production and hence the cost of production. Good quality of these systems results in good quality of investment where they are used. There is big competition on aluminium system market. The product competition decides about the existence of the manufacturer on the market. Therefore, it was decided to use the $3 \times 3$ matrix to evaluation manufacturing technology of aluminium systems produced by chosen Polish company for building industry. This matrix can be easily used to evaluate the technology of any aluminium products. From the analysis presented in the paper it results that the research company is located in area 9 of the 3x3 matrix, i.e. "Search for occasions", and the factors which decided about this position were evaluated by staff at the medium level.

Keywords: aluminium systems, technology possibilities, product competition, $3 x 3$ matrix

\section{References}

[1] KLIMECKA-TATAR, D. (2014). The Powdered Magnets Technology Improvement by Biencapsulation Method and Its Effect on Mechanical Properties. In: Manufacturing Technology, Vol.14, No. 1, pp.30-36.

[2] SYGUT, P., LABER, K., BORKOWSKI, S. (2012). Investigation of the non-uniform temperature distribution on the metallic charge length during round bars rolling process. In: Manufacturing Technology, Vol. 12, No. 13, pp. 260-263.

[3] KARDAS, E. (2010). A technical and economic analysis of pig iron production. In: Materials Science Forum, Vol. 638-642, pp. 3291-3296.

[4] KOTUS, M., HOLOTA, T., PAULIČEK, T., PETRÍK, M., SKLENÁR, M. (2013). Quality and reliability of manufacturing process in automation of die-casting. In: Advanced Materials Research, vol. 801, special iss., pp 103107.

[5] LESTYÁNSZKA ŠKU゚RKOVÁ, K.; KUDIČOVÁ, J. (2011). The process capability study of pressing process for force closed. In: Vedecké práce MtF STU v Bratislave so sídlom v Trnave. Research papers Faculty of Materials Science and Technology Slovak University of Technology in Trnava, v. 19, n. 30, p. 51-57.

[6] BORKOWSKI, S., CZAJKOWSKA, A. (2010). Analysis of the Structure of Downtime Affecting the Level of Non-Conforming Products in Die Casting. In: International Journal of Applied Mechanics and Engineering, Vol.15, No 2, pp.557-562.

[7] KADŁUBEK, M. (2014). Identification of the Distribution Structure in Chosen Metallurgical Enterprise. In: METAL 2014: 23rd Anniversary International Conference on Metallurgy and Materials. pp. 1546-1551. Ostrava: TANGER.

[8] LOWE, P. (1995). Management of Technology: Perception and Opportunities. London: Chapman \& Hall.

[9] INGALDI, M. (2014). Use of the SWOT ANALYSIS and 3x3 matrix to determine the technological position of the chosen metal company. In: Acta Metallurgica Slovaca - Conference, Vol.4, 2014. pp. 1338-1660.

[10]BORKOWSKI, S., INGALDI, M. (2013). Workers Evaluations of Ribbed Wire Competition and Rolling Mill Technological Possibilities. In: METAL 2013: 22nd International Conference on Metallurgy and Materials. pp. 1920-1925. Ostrava: TANGER.

[11]INGALDI, M., BORKOWSKI, S. (2013). Management of the Technical Possibilities and Product Competition in the Market in the Chosen Company. In: Nauka i obrazovanie transportu. Materialy VI Mezdunarodnoj naucnoprakticeskoj konferencii, posvascennoj 40-letiu Samarskogo gosudarstvennogo universiteta putej soobscenia. 5-7 noabra 2013 g. p. 104-107. Samara. Pub. Samara: SamGUPS. 